\title{
The Artificial-rumen Technique for Estimating the Nutritive Value of Forages'
}

\author{
José A. Arroyo-Aguilú, Joseph L. Evans, and M. Wight Taylor ${ }^{2}$
}

\section{INTRODUCTION}

The nutritive evaluation of a forage comprises not only the determination of its crude nutrient content but also its acceptability and the digestibility and availability of the nutrients. In the past forage evaluations have been performed by conventional digestibility trials which require considerable time, labor, and equipment. It now seems probable that reliable evaluations can be secured by means of simple, accurate laboratory techniques which are less costly and less time-consuming. The laboratory techniques which have been suggested for measuring nutritive value are relatively simple, but they need further testing. The development of one of these techniques, the artificial rumen, for the study of in vitro cellulose digestion, offers a method of estimating the nutritive value of forages.

One purpose of this study was to evaluate by in vitro techniques three of the more important forages of New Jersey: Orchardgrass (Dactylis glomerata), bromegrass (Bromus inermis), and timothy (Phleum pratense). However, the primary objective was to study the in vitro fermentation technique as a biological method for evaluating feedstuffs, especially forages, as to intake and digestibility for ruminant animals. The criterion of measurement was in vitro cellulose digestion at 12 and 24 hours.

\section{REVIEW OF LITERATURE}

In establishing in vitro studies in artificial rumen systems, Warner $(15)^{3}$ suggested several precautions which should be observed. Throughout the test period there should be an adequate and constant number of microorganisms, and continued motility of these micro-organisms, with large

1 Paper of the Journal Series, New Jersey Agricultural Experiment Station, Rutgers, The State University, New Brunswick, N.J. Data presented are taken in part from a thesis submitted to the Graduate Faculty in partial fulfillment of the requirements for the degree of Master of Science.

${ }^{2}$ Assistant Biochemist, Animal Husbandry Department, Agricultural Experiment Station, University of Puerto Rico, Río Piedras, P.R.; Assistant Professor of Nutrition, Dairy Science Department, Rutgers University, New Brunswick, N.J.; and Chairman, Agricultural Biochemistry Department, Rutgers University, New Brunswick, N.J., respectively. The senior author wishes to express his sincere appreciation to Director Arturo Roque, Agricultural Experiment Station, University of Puerto Rico, for his interest in granting a leave of absence to pursue graduate work.

${ }^{3}$ Italic numbers in parenthesis refer to Literature Cited, pp. 178-9. 
numbers of dividing protozoa. The length of incubation should be limited to the period during which normal rates of cellulose, starch, and protein digestion, and normal interactions between these processes can be observed. Optimum cellulolytic activity also requires proper $\mathrm{pH}$, substrate concentration, and temperature.

Huhtamen et al. (8) used a 24-hour fermentation period in their miniature artificial rumen. This artificial rumen was capable of maintaining the rumen bacteria during the period of active fermentation in approximately the same proportions as they are found in the intact rumen.

A technique based on the use of washed suspensions of rumen microorganisms was developed by Cheng et al. (2) for the study of in vitro cellulose digestion. They observed that percentage cellulose digestion declined in a linear manner as substrate concentration increased.

Hungate (9) and Warner (15) suggested that the microbiological population in an artificial rumen incubated for a period longer than 24 hours of ten bears little relation, at the end of a run, to that at the beginning.

Kamstra et al. (10) demonstrated that maturity of plant material has an effect upon cellulose digestion-the young-plant cellulose being the more digestible. A decrease in in vitro cellulose digestion with each advancing maturity stage of timothy hay was shown by Lloyd et al. (11).

Baumgardt et al. (1) found that the measurement of ruminant cellulose digestion is a very good indication of the digestibility of the forage. This was accomplished by measuring the in vitro digestion of cellulose in certain forage samples, and comparing these data with the results of digestion trials with steer fed the same material. He found, in confirmation of others, that ruminant animals were able to obtain all or nearly all their feed nutrients from forages. This was possible because of the large number of cellulolytic micro-organisms which inhabit the rumen and because of the large volume of the rumen.

Crampton et al. (3) computed the relative intake, "R.I." being a term expressing the relation between the observed and the expected intake of a standard forage on a percentage basis, of a forage consumed by sheep, by using the formula given in footnote 2 of table 1 . They also proposed that the R.I. of a forage times its energy digestibility, expressed as a fraction, be used as a nutritive value index (N.V.I.). Thus, when we know the N.V.I. of feedstuffs fed and the maintenance requirement of the animal receiving these nutrients, productive potentiality can be predicted.

Donefer et al. (5) attempted to find an in vitro method which would accurately estimate in vivo N.V.I. They arrived at the equation: $Y=-8.7$ $+1.314 X$, wherein $X$ equals in vitro cellulose digestion and $Y$ equals in vivo N.V.I. 


\section{MATERIALS AND METHODS}

Nine forage samples (table 1) of known nutritive value were used as controls. Other forage samples were harvested for in vilro evaluation on four different dates: May 5, May 15, May 25, and June 6. These samples represented first cuttings and were collected at three different locations, northern, central, and southern, within the State of New Jersey. The orchardgrass plots were fertilized with, 0,50 , and 100 pounds of nitrogen per acre, while the timothy and bromegrass plots were fertilized with 50 pounds

TABLE 1.-Percenlage digestibility dala for forages of known nutritive value

\begin{tabular}{|c|c|c|c|c|c|c|c|}
\hline \multirow{2}{*}{ Sample No. } & \multirow{2}{*}{ Forage grass } & \multicolumn{2}{|c|}{ T.D.N. } & \multirow{2}{*}{ R.I.2 } & \multirow{2}{*}{ N.V.I. ${ }^{2}$} & \multicolumn{2}{|c|}{$\begin{array}{l}\text { Results of in } \\
\text { vilro cellulose } \\
\text { digestion for- }\end{array}$} \\
\hline & & Actual & $\begin{array}{c}\text { Bio- } \\
\text { logicals }\end{array}$ & & & $\begin{array}{c}12 \\
\text { hours }\end{array}$ & $\begin{array}{c}24 \\
\text { hours }\end{array}$ \\
\hline 57 & Brome & 58.2 & 59.5 & 82.5 & 48.1 & 18.0 & 39.7 \\
\hline 58 & do. & 58.7 & 56.9 & 84.2 & 49.4 & 18.4 & 37.6 \\
\hline 59 & do. & 62.4 & 61.5 & 79.3 & 49.5 & 16.3 & 41.4 \\
\hline 61 & Orchard & 52.2 & 52.8 & 114.1 & 59.6 & 20.1 & 34.1 \\
\hline 75 & do. & 58.0 & 57.7 & 94.2 & 54.6 & 24.0 & 38.2 \\
\hline 63 & do. & 57.5 & 58.4 & 116.1 & 66.8 & 21.0 & 38.8 \\
\hline 81 & Timothy & 67.0 & 67.3 & 112.9 & 75.6 & 23.8 & 46.3 \\
\hline 82 & do. & 67.6 & 67.5 & 115.9 & 78.3 & 17.9 & 46.5 \\
\hline 83 & do. & 66.2 & 66.1 & 113.4 & 75.1 & 21.8 & 45.3 \\
\hline
\end{tabular}

1 Biological T.D.N. (percent) $=12.2+1.19 X ; X=24$-hour in vitro cellulose digestion.

${ }^{2}$ R.I. (percent) $=\frac{\text { Observed intake }(\mathrm{gm} .) \times 100}{80\left(\mathrm{w}_{\mathrm{kg} .} 0.75\right)}$.

${ }^{3}$ N.V.I. (percent) $=\frac{\text { R.I. (percent) } \times \text { actual T.D.N. (percent) }}{100}$.

of nitrogen per acre. The 50-pound orchardgrass plots were replicated, and, in all, 52 samples were collected.

\section{PHOSPHATE BUFFER}

The composition of buffer mineral solutions used in artificial-rumen systems is based upon the composition of ruminant saliva as given by McDougal (13).

Two buffer-mineral solutions, McDougal's and a phosphate buffer, were tested with two duplicate low- and high-nitrogen bromegrass samples during 24-hour fermentation periods. The results indicated that the phosphate buffer solution supported the greater cellulose digestion. The composition 
of this phosphate buffer was $\mathrm{NaHCO}_{3}, 3.885 ; \mathrm{Na}_{2} \mathrm{HPO}_{4}, 0.598 ; \mathrm{NaH}_{2} \mathrm{PO}_{4}$. $\mathrm{H}_{2} \mathrm{O}, 2.000 ; \mathrm{KCl}, 0.572$; urea, 1.070 ; and glucose, 1.00 gm. per liter.

The phosphate buffer solution was warmed to $39^{\circ} \mathrm{C}$. each time before use, and was adjusted to $\mathrm{pH} 6.8-6.9$ by vigorous bubbling with $\mathrm{CO}_{2}$. Perhaps this adjustment could be made by the addition of $\mathrm{HCl}$ or $\mathrm{NaOH}$ when necessary.

\section{RUMEN FLUID INOCULUM}

A rumen-fistulated cow fed a pelleted ration of timothy hay, corncobs, corn grain, and alfalfa-leaf meal, served as the source of rumen-fluid inoculum. The night before the collection the water consumption was curtailed so as to control the dilution of the inoculum with respect to rumen microorganisms. The rumen fluid was collected by way of the fistula and first strained by squeezing through four layers of cheesecloth. Just before using it was filtered again through four layers of cheesecloth in the laboratory.

\section{AMOUNT OF SUBSTRATE}

A 1-gm. sample of forage was used as the substrate source in cellulosedigestion determinations. Baumgardt et al. (1) concluded that a sample of forage of this size would offer a suitable quantity, 0.15 to $0.35 \mathrm{gm}$. of cellulose, even allowing for extremes in cellulose content. However, this range of substrate size had a significant negative linear effect upon cellulose digestion, Evans et al. (6). Therefore, $0.3 \mathrm{gm}$. of cellulose substrate was chosen as a standard and corrections were made to this basis in all samples tested.

\section{ARTIFICIAL-RUMEN SYSTEM}

One-gram samples of ground hay were weighed into $100-\mathrm{ml}$. beakers without pouring lips. Twenty milliliters of the rumen-fluid inoculum and $30 \mathrm{ml}$. of the phosphate buffer solution were added to each beaker and mixed gently with the hay substrate.

Carbon dioxide was passed over the surface of the beaker contents. Immediately the beakers were elosed with stoppers, equipped with Bunsentype valves, and placed in an incubator maintained at a temperature of $39^{\circ} \mathrm{C}$. They were swirled at least once during the fermentation period to release trapped gas.

Twelve- and twenty-four-hour fermentation samples of the same hay were run each time. The same sets of samples were run on two consecutive days to account for day-to-day variation.

A beaker containing a 0.5 -gm. sample of crystalline cellulose to serve as an internal cellulose standard was always included in each run. An 80$\mathrm{ml}$. rumen-fluid sample was also collected for analysis to account for the 
cellulose added by the rumen fluid. Forage samples of known nutritive value were included in each run. These samples, plus the internal standard, were used in making corrections for day-to-day variations.

At the end of the fermentation period the beakers were removed from the incubator, and $1 \mathrm{ml}$. of $2 \mathrm{~N} \mathrm{H}_{2} \mathrm{SO}_{4}$ was added to each beaker to stop microbial activity. They were then placed in an oven at $70^{\circ} \mathrm{C}$. and the samples were allowed to dry.

Cellulose was determined by the method of Crampton and Maynard (4) as modified by Matrone (12):

In vitro cellulose digestion (percent) $=$

$$
1.00-\left(\frac{\begin{array}{c}
\text { grams of cellulose remaining after digestion } \\
\text { in artificial rumen }
\end{array}}{\begin{array}{c}
\text { grams of cellulose in hay }+ \text { grams of cellulose } \\
\text { in } 20 \mathrm{ml} \text {. of rumen fluid after digestion }
\end{array}}\right) \times 100 .
$$

TABLE 2.-Average data (percentage) on the biological T.D.N. of bromegrass, orchardgrass, and timothy samples at different dates of harvest

\begin{tabular}{l|c|c|c|c}
\hline \multirow{2}{*}{ Forage grass! } & \multicolumn{4}{|c}{ Data for indicated harvest dates2 } \\
\cline { 2 - 5 } & May 5 & May 15 & May 25 & June 6 \\
\hline Brome & $65.0 \pm 2.16$ & $57.0 \pm 1.14$ & $52.7 \pm 2.45$ & $46.5 \pm 2.97$ \\
Orchard & $73.2 \pm 6.36$ & $65.0 \pm 4.08$ & $58.0 \pm 6.53$ & $45.3 \pm 3.15$ \\
Timothy & $71.1 \pm .53$ & $62.8 \pm 2.58$ & $56.1 \pm 3.16$ & $48.2 \pm 4.03$ \\
\hline
\end{tabular}

${ }^{1}$ Fertilized with $50 \mathrm{lb}$. nitrogen per acre on the average date of Apr. 21. One plot of orchard received no nitrogen and another received $100 \mathrm{lb}$. The brome plots were located in northern and central but not in southern New Jersey.

2 The regression equation which expressed the reduction in T.D.N. $(Y)$ with advancing maturity in days $(X)$ after Apr. 30 was $Y=76.6-0.8 X$.

Nine forages of known nutritive value were used as controls in this study. Data on the control samples were used to calculate the regression equation for determining the "biological T.D.N." of all the samples which were collected and analysed. All data are reported on a dry-matter basis.

The term "biological T.D.N." is the name given to the value calculated from the 24-hour in vitro cellulose-digestion value. These values, as well as other data for the nine known forages, are given in table 1 . These control samples were tested in conventional digestion trials with cattle at the New Jersey Agricultural Experiment Station. By means of the regression equation, biological T.D.N. was calculated for all samples (table 2) and was tested statistically using Snedecor's analysis of variance (14). R.I. was determined by using the equation of Crampton et al. (B). The N.V.I. was ob- 
tained by multiplying the R.I. by actual T.D.N. and expressing it on a percentage basis.

\section{RESULTS}

TWELVE-HOUR IN VITRO CELLULOSE DIGESTION

The rates of in vitro digestion of forage cellulose for 12-hour periods were examined for correlation with R.I. and N.V.I. (table 3), as proposed by Donefer et al. (5). These workers reported very good correlations between 12-hour cellulose digestion and R.I. or N.V.I. with correlation coefficients of 0.83 and 0.91 , respectively. Therefore the same comparisons were made in this study.

The correlation coefficients $(r)$ between R.I. and 12-hour in vitro cellulose digestion and N.V.I. and 12-hour in vitro cellulose digestion found in the present study were 0.48 and 0.41 , respectively, which conflict with the results of Donefer el al. (5). These lower correlations were probably due to the lag periods which were displayed by the rumen micro-organisms at the start of cellulose digestion, as discussed by Donefer et al. (5). Unpublished data by Evans and Stoker, New Jersey Agricultural Experiment Station, showed a correlation coefficient between R.I. of cattle and 12-hour in vitro cellulose digestion of 0.82 .

The shock in transfer, variations of technique, and poor initial availability of the nutrients could account for these activity characteristics of the micro-organisms when the rumen fluid was transferred from the cow's rumen to an artificial system. The period elapsing during the transfer of rumen fluid could bring about changes in $\mathrm{pH}$ and temperature which would affect the number and motility of micro-organisms and slow down the rate of cellulose digestion at the start of the fermentation. The continued growth and division of the micro-organisms is dependent upon the availability of the nutrients and this, in turn, is necessary to carry out the in vitro fermentation process.

The intake data for the forages of known nutritive value were obtained in connection with digestibility studies and had been considered to be of secondary importance when collected. As a result, the preliminary periods were perhaps too short in duration to establish a persistently maximum rate of intake. Further research is indicated in order to increase the precision of the data used in calculating the regression equations.

\section{TWENTY-FOUR-HOUR IN VITRO CELLULOSE DIGESTION}

Actual T.D.N. and digestible-energy values were correlated with 24-hour in vitro cellulose digestion (table 3 ), as proposed by Donefer $e$ al. (5). N.V.I. was compared with both 24 -hour and $12-\times 24$-hour in vitro cellulose digestion. Kamstra et al. (10) determined that 24-hour in vitro cellulose di- 
gestion is essentially a measure of characteristic "leveling-off" of rate of digestion. From the data in the present study (table 3), the regression equations to predict biological T.D.N. $(Y)$ and digestible energy $(Y)$ from 24-hour in vitro cellulose digestion $(X)$ were $Y=12.2+1.19 X$ and $Y=$ $0.75+0.05 X$, respectively. These equations were found to be statistically significant $(P<0.01)$ and to have correlation coefficients of 0.98 and 0.90 ,

TABLE 3.-Simple correlations calculated from table 1 for forages of known nutritive value

\begin{tabular}{|c|c|c|}
\hline Variables correlated & Regression equation & $\begin{array}{c}\text { Correlation } \\
\text { coefficient' }(r)\end{array}$ \\
\hline $\begin{array}{l}\text { Actual T.D.N. }(Y) \text { with } 24 \text {-hour in } \\
\text { vitro cellulose digestion }(X)\end{array}$ & $Y=12.2+1.19 X$ & $0.98^{* *}$ \\
\hline $\begin{array}{l}\text { Actual digestible energy (Kcal./gm.) } \\
(Y) \text { with } 24 \text {-hour in vitro cellulose di- } \\
\text { gestion }(X)\end{array}$ & $Y=.75+.05 X$ & $.90^{* *}$ \\
\hline $\begin{array}{l}\text { N.V.I. }(Y) \text { with } 24 \text {-hour in vitro cellu- } \\
\text { lose digestion }(X)\end{array}$ & $Y=19.9+2.00 X$ & $.70^{*}$ \\
\hline $\begin{array}{l}\text { N.V.I. }(Y) \text { with } 12 \text {-hour } \times 24 \text {-hour in } \\
\text { vitro cellulose digestion }(X)\end{array}$ & $Y=14.2+5.79 X$ & $.71^{*}$ \\
\hline $\begin{array}{l}\text { N.V.I. }(Y) \text { with } 12 \text {-hour in vitro cellu- } \\
\text { lose digestion }(X)\end{array}$ & $Y=24.3+1.86 X$ & .41 \\
\hline $\begin{array}{l}\text { R.I. }(Y) \text { with 12-hour in vitro cellulose } \\
\text { digestion }(X)\end{array}$ & $Y=43.6+2.86 X$ & .48 \\
\hline
\end{tabular}

$1 *$ Significant at the 5 -percent level of probability $(\mathrm{P}<0.05)$; ${ }^{* *}$ significant at the 1-percent level of probability $(\mathrm{P}<0.01)$.

indicating the close relationship between the values obtained in the artificial rumen and those obtained in the animal.

\section{DISCUSSION}

Similar equations and correlation coefficients $(r)$ were found by Hershbeger et al. (7), Baumgardt et al. (1), and Donefer et al. (5), who worked with alfalfa, red clover, birdsfoot trefoil, bromegrass, timothy, orchardgrass, reed canarygrass, and Kentucky bluegrass, using similar artificial-rumen techniques. These workers found the following correlation coefficients $(r)$, respectively: $0.92,0.85$, and 0.87 . Thus, it appears that in vitro study with the artificial-rumen technique offers a promising tool for the rapid evaluation of the digestibility of forage crops. 
Because of the highly significant correlation obtained between both actual T.D.N. and digestible energy and 24-hour in vitro cellulose digestion, 24-hour fermentation periods were considered quite satisfactory. Although longer periods were not tested in the present study, Baumgardt et al. (1) determined that there was no advantage in extending the fermentation period to 48 hours, insofar as the estimation of digestible energy was concerned. He also observed that mold growth was evident at 30 hours on the hay substrate surface.

The correlation coefficients $(r)$ between N.V.I. and 24-hour in vitro cellulose digestion and N.V.I. and 12-hour $\times 24$-hour in vitro cellulose digestion were found to be 0.70 and 0.71 , respectively.

It was determined that decreasing biological T.D.N. values (table 2) were obtained with advancing dates of harvest of first-growth bromegrass, orchardgrass, and timothy forages $(P<0.01)$. An average daily loss of 0.8 T.D.N. percentage unit was found for each day of additional growth or increasing maturity after April 30 and through June 6. Harvesting the first-growth with reference to the calendar has definite advantages, even though many forage specialists still recommend harvesting at a given stage of plant maturity. Since the farming business is a series of irregular management problems, both specialized and complex, controlled to a great degree by environmental conditions, any event that can be anticipated to occur at a definite time will relieve some of the management pressure. Therefore, harvesting forage at the recommended date helps to simplify planning and management. ${ }^{4}$

\section{SUMMARY AND CONCLUSIONS}

Nine forages of known nutritive value, as determined in conventional digestibility trials with cattle, were used as controls to further evaluate the artificial rumen or in vitro cellulose fermentation technique at 12 and 24 hours with the following results.

The correlation of the relative intake (R.I.) and of the nutritive value index (N.V.I.) with 12-hour in vitro cellulose digestion was by no means the best. Low correlation coefficients $(r)$ of 0.48 and 0.41 , respectively, were obtained. Further research is needed to improve the efficiency and precision of the 12-hour fermentation.

The 24-hour in vitro cellulose digestion in the artificial rumen gave the best estimates of the apparent digestibility of forages. Regression equations to predict biological T.D.N. ( $Y$ ) and digestible energy (K cal./gm.) $(Y)$ from 24-hour in vitro cellulose digestion $(X)$ were calculated: $Y=$

- Additional data concerning date of harvest of New Jersey forage will be presented in a future N.J. Agricultural Experiment Station Circular, New Brunswick, N.J. 
$12.2+1.19 X$ and $Y=0.75+0.05 X$, and highly significant correlations of 0.98 and 0.90 were obtained. By means of these equations, the biological T.D.N. and digestible energy were calculated for all samples, and the results were tested statistically by means of the analysis of variance.

N.V.I. correlated to 24-hour in vitro cellulose digestion and to 12-hour $\times$ 24-hour in vitro cellulose digestion gave coefficients of 0.70 and 0.71 , respectively.

In addition to the control samples, different forages, bromegrass, orchardgrass, and timothy from 13 different plots harvested on 4 first-cutting dates at 3 different locations in northern, central, and southern New Jersey, and fertilized with a complete fertilizer containing 50 pounds of nitrogen per acre, 1 plot receiving no nitrogen and 1 plot 100 pounds, were used in this study. They were evaluated by means of the artificial-rumen or in vitro cellulose-fermentation technique as a biological means of estimating their nutritive value. Advancing harvest dates (May 5 to June 6) were found to decrease the biological T.D.N. of orchardgrass, timothy, and bromegrass by 0.80 T.D.N. percentage units per day.

It can be concluded that the 24-hour in vitro cellulose digestion can be used as a means of estimating the digestibility of forages or to predict T.D.N., or digestible energy, but the use of this 12-hour in vitro cellulosedigestion technique to predict intake or N.V.I. for cattle requires further refinement and precision.

\section{RESUMEN Y CONCLUSIONES}

Nueve forrajes, cuyo valor nutritivo ha sido determinado en pruebas convencionales de digestibilidad en ganado vacuno, se usaron como controles para evaluar la técnica del rumen artificial (técnica de digestión de celulosa in vitro), a las 12 y a las 24 horas, con los siguientes resultados.

La correlación del consumo relativo y del índice de valor nutritivo con la digestión de celulosa in vitro a las 12 horas no fue necesariamente la mejor. Los coeficientes de correlación obtenidos, de 0.48 y 0.41 , respectivamente, resultaron bajos. Para mejorar la eficiencia y precisión de la digestión a las 12 horas es necesario hacer investigaciones adicionales.

La digestibilidad de celulosa in vitro a las 24 horas en el rumen artificial reveló datos más precisos para determinar la digestibilidad aparente en las yerbas forrajeras. Se calcularon las siguientes ecuaciones de regresión para pronosticar "biológicamente" los nutrientes totalmente digeribles (porciento de N.T.D.) ( $Y$ ) y energía digerible ( $\mathrm{K}$ cal./gm.) ( $Y$ ) de la digestión de celulosa in vitro a las 24 horas $(X): Y=12.2+1.19 X$ y $Y=$ $0.75+0.05 X$ y se obtuvieron correlaciones de 0.98 y 0.90 , respectivamente. Usando estas ecuaciones, se calculó el N.T.D. biológico y la energía 
digerible en todas las muestras y los resultados se comprobaron estadísticamente el análisis de variancia.

La correlación del índice de valor nutritivo con la digestión de celulosa in vitro a las 24 horas y con la digestión de celulosa in vitro a las $12 \times 24$ horas resultó en coeficientes de 0.70 y 0.71 , respectivamente.

En adición a las muestras usadas como controles, también se usaron en este estudio muestras de distintas yerbas forrajeras, tales como bromo liso (Bromus inermis), pasto apelotonado o pasto de huerta (Dactylis glomerata), y fleo (Phleum pratense), de 13 parcelas diferentes en las regiones norte, central y sur del estado de Nueva Jersey. Estas yerbas de primer corte se cosecharon en cuatro fechas distintas y se abonaron con una fórmula completa conteniendo 50 libras de nitrógeno por acre, a excepción de una parcela a la que no se le aplicó nitrógeno y otra a la que se le aplicaron 100 libras. Se evaluaron estas yerbas usando la técnica del rumen artificial o de digestión de celulosa in vitro como un medio biológico para estimar su valor nutritivo. Se encontró que, según avanzaba la cosecha, desde el 5 de mayo hasta el 6 de junio, el N.T.D. biológico de bromo liso, pasto de huerta y fleo disminuía 0.80 de un por ciento diariamente.

Se puede concluír que la digestión de celulosa in vitro a las 24 horas puede servir para determinar la digestibilidad de los forrajes o para pronosticar los N.T.D. o la energía digerible, pero que el uso de esta técnica para pronosticar el consumo relativo o el índice de valor nutritivo en ganado vacuno requiere una técnica más refinada y precisa.

\section{LITERATURE CITED}

1. Baumgardt, B. R., Taylor, M. W., and Cason, J. L., Evaluation of forages in the laboratory, II, Simplified artificial rumen procedure for obtaining repeatable estimates of forage nutritive value, J. Dairy Sci. 45 62-8, 1962.

2. Cheng, E. W., Hall, G., and Burroughs, W., A method for the study of cellulose digestion by washed suspensions of rumen micro-organisms, J. Dairy Sci. 38 1225-30, 1955.

3. Crampton, E. W., Donefer, E., and Lloyd, L. E., A nutritive value index for forages, J. Anim. Sci. 19 538-44, 1960.

4. Crampton, E. W., and Maynard, L. A., The relation of cellulose and lignin content to the nutritive value of animal feeds, J. Nutr. 15 383-95, 1938.

5. Donefer, E., Crampton, E. W., and Lloyd, L. E., Prediction of the nutritive value index of a forage from in vitro rumen fermentation data, J. Anim. Sci.19 545-52, 1960.

6. Evans, J. L., Arroyo-Aguilú, J., Chalupa, W. V., Stillions, M. C., and Taylor, $M$. W., Substrate level and nitrogen supplementation influence upon in vitro forage evaluation, (abs.), J. Dairy Sci.45 1575-6, 1962.

7. Hershberger, T. V., Long, 'T. A., Hartsook, E. W., and Swift, R. W., Use of the artificial rumen technique to estimate the nutritive value of forages, J. A nim. Sci. 18 770-9, 1959.

8. Huhtamen, C. M., Saunders, R. K., and Gall, L. S., Fiber digestion using the miniature artificial rumen, J. Dairy Sci. 37 328-35, 1954. 
9. Hungate, R. E., Symposium on microbiology of the rumen, Bact. Revs. 19 277-9, 1955.

10. Kamstra, L. D., Moxon, A. L., and Bentley, O. G., The effect of stage of maturity and lignification of the digestion of cellulose in forage plants by rumen microorganisms in vitro, J. A nim. Sci. 17 199-208, 1958.

11. Lloyd, L. E., Jeffers, H. F. M., Donefer, E., and Crampton, E. W., Effect of four maturity stages of timothy hay on its chemical composition, nutrient digestibility and nutritive value index, J. Anim. Sci. 20 468-73, 1961.

12. Matrone, G., A Study of Lignin and Cellulose Methods for the Chemical Evaluation of Feeds, M. S. Thesis, Cornell University, Ithaca, N.Y., 1944.

13. McDougal, A. I., Studies on ruminant saliva, I, Composition and output of sheep saliva, Biochem. J. 43 99-109, 1948.

14. Snedecor, G. W., Statistical Methods, 5th ed., Iowa State College Press, Ames, Iowa, 1956.

15. Warner, A. C. I., Criteria for establishing the validity of in vitro studies with rumen micro-organisms in so-called artificial rumen systems, J. Gen. Microbiol. 14 733-48, 1956. 